\title{
Needs and Requirements for Future Research Reactors (ORNL Perspectives)
}

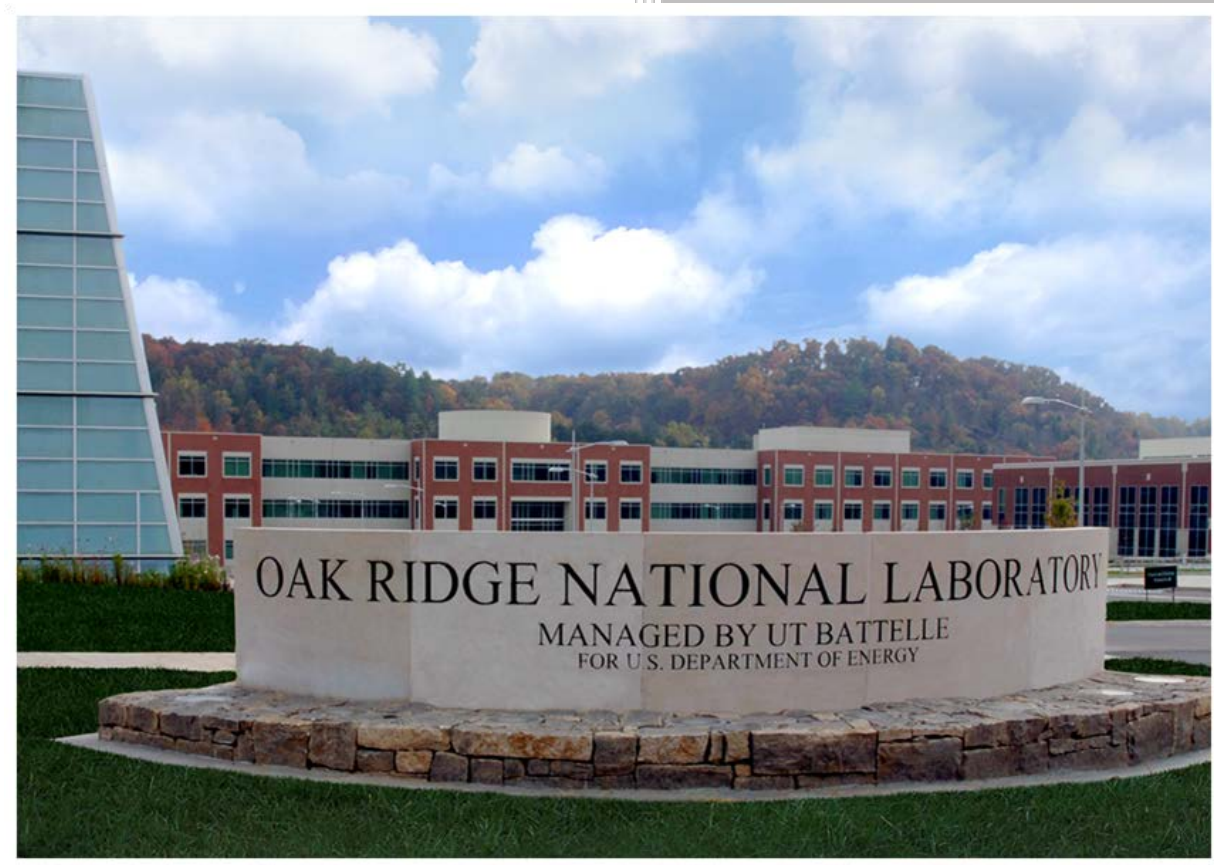

Approved for public release. Distribution is unlimited.
Germina llas Chris Bryan Jess Gehin

February 10, 2016 


\title{
DOCUMENT AVAILABILITY
}

Reports produced after January 1, 1996, are generally available free via US Department of Energy (DOE) SciTech Connect.

\section{Website http://www.osti.gov/scitech/}

Reports produced before January 1, 1996, may be purchased by members of the public from the following source:

\author{
National Technical Information Service \\ 5285 Port Royal Road \\ Springfield, VA 22161 \\ Telephone 703-605-6000 (1-800-553-6847) \\ TDD 703-487-4639 \\ Fax 703-605-6900 \\ E-mail info@ntis.gov \\ Website http://www.ntis.gov/help/ordermethods.aspx
}

Reports are available to DOE employees, DOE contractors, Energy Technology Data Exchange representatives, and International Nuclear Information System representatives from the following source:

Office of Scientific and Technical Information

PO Box 62

Oak Ridge, TN 37831

Telephone 865-576-8401

Fax 865-576-5728

E-mail reports@osti.gov

Website http://www.osti.gov/contact.html

This report was prepared as an account of work sponsored by an agency of the United States Government. Neither the United States Government nor any agency thereof, nor any of their employees, makes any warranty, express or implied, or assumes any legal liability or responsibility for the accuracy, completeness, or usefulness of any information, apparatus, product, or process disclosed, or represents that its use would not infringe privately owned rights. Reference herein to any specific commercial product, process, or service by trade name, trademark, manufacturer, or otherwise, does not necessarily constitute or imply its endorsement, recommendation, or favoring by the United States Government or any agency thereof. The views and opinions of authors expressed herein do not necessarily state or reflect those of the United States Government or any agency thereof. 
Reactor and Nuclear System Division

Research Reactors Division

\section{NEEDS AND REQUIREMENTS FOR FUTURE RESEARCH REACTORS (ORNL PERSPECTIVES)}

\section{Germina Ilas \\ Chris Bryan \\ Jess Gehin}

Date Published: February 10, 2016

Prepared by

OAK RIDGE NATIONAL LABORATORY

Oak Ridge, TN 37831-6283

managed by

UT-BATTELLE, LLC

for the

US DEPARTMENT OF ENERGY

under contract DE-AC05-00OR22725 



\section{CONTENTS}

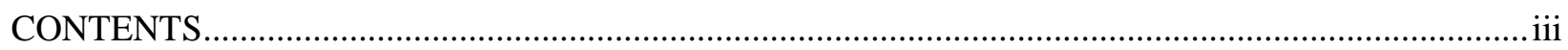

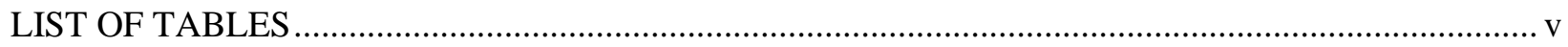

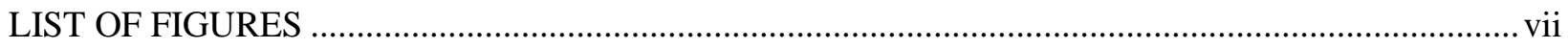

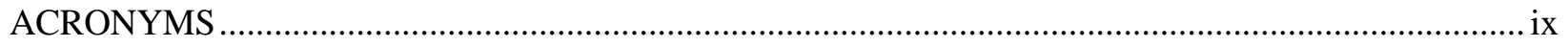

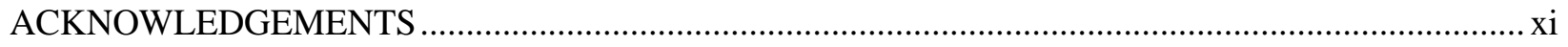

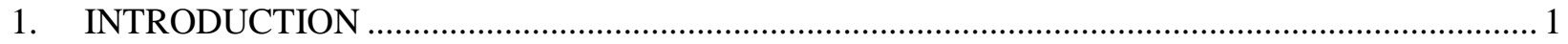

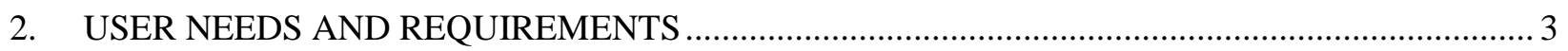

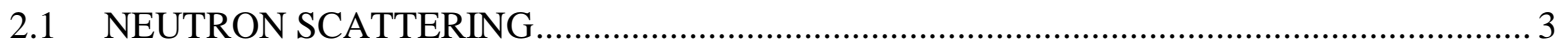

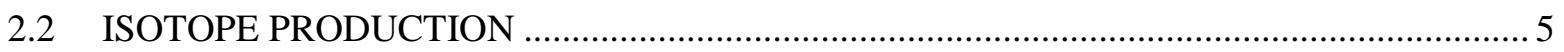

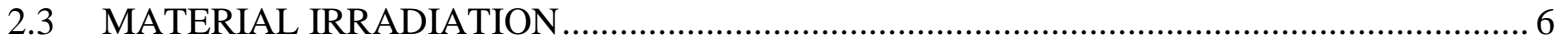

3. GENERAL CONSIDERATIONS - LOOKING TOWARD FUTURE RESEARCH

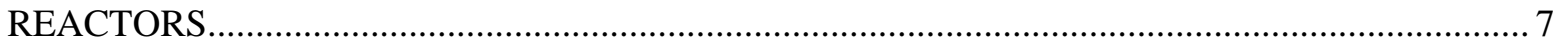

4. OVERVIEW OF CAPABILITIES WORLDWIDE …..............................................................

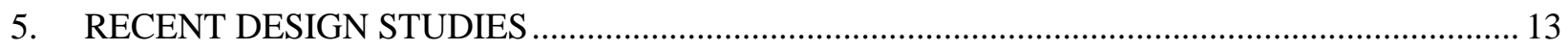

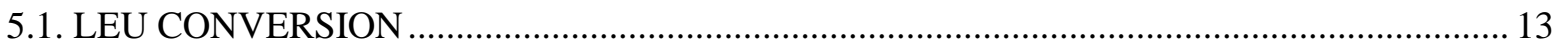

5.2. DESIGN EFFORTS FOR FUTURE RESEARCH REACTORS .............................................. 14

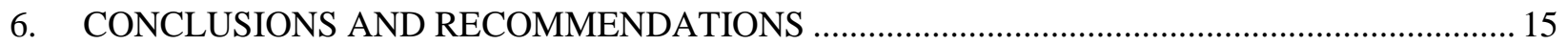

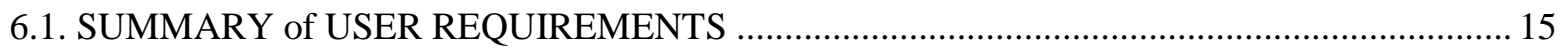

6.2. FEEDBACK ON STRATEGY FOR A NEW ORNL RESEARCH REACTOR....................... 15

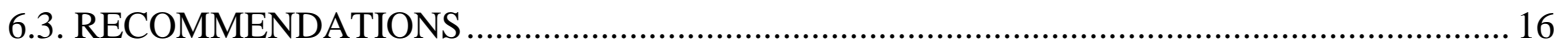

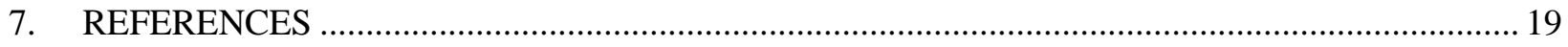

APPENDIX A: AGENDA OF THE ORNL WORKSHOP ON MAY 12, 2015 ....................................3 


\section{LIST OF TABLES}

1. Main characteristics [4] of HFIR peer-level high performance research reactors ................................ 11

2. Main characteristics of JHR, PIK, and MBIR research reactors....................................................... 12 


\section{LIST OF FIGURES}

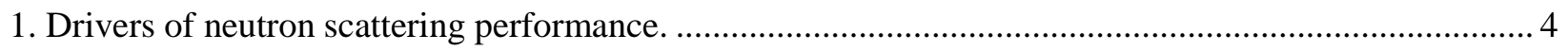




\section{ACRONYMS}

\begin{tabular}{|c|c|}
\hline ANS & Advanced Neutron Source \\
\hline ATR & Advanced Test Reactor \\
\hline CARR & China Advanced Research Reactor \\
\hline CASL & Consortium for Advanced Simulation of Light Water Reactors \\
\hline CEA & Commisariat à l'Énergie Atomique \\
\hline CERCA & $\begin{array}{l}\text { Compagnie pour l'Étude et la Réalisation de Combustibles Atomiques (Company for the } \\
\text { Study of Atomic Fuel Creation) }\end{array}$ \\
\hline $\begin{array}{l}\text { DOE } \\
\text { dpa }\end{array}$ & $\begin{array}{l}\text { US Department of Energy } \\
\text { displacement per atom }\end{array}$ \\
\hline FRM II & Forschungs-Neutronenquelle Heinz Maier-Leibnitz reactor \\
\hline GTRI & Global Threat Reduction Initiative \\
\hline HEU & highly-enriched uranium \\
\hline HFETR & High-Flux Engineering Test Reactor \\
\hline HFIR & High Flux Isotope Reactor \\
\hline HPRR & high performance research reactor \\
\hline IAEA & International Atomic Energy Agency \\
\hline IGORR & International Group of Research Reactors \\
\hline ILL & Institut Laue-Langevin \\
\hline INL & Idaho National Laboratory \\
\hline JHR & Jules Horowitz Reactor \\
\hline LEU & low-enriched uranium \\
\hline MITR & Massachusetts Institute of Technology Reactor \\
\hline MOX & mixed oxide fuel \\
\hline MTR & material testing reactor \\
\hline MURR & Missouri University Research Reactor \\
\hline NAA & neutron activation analysis \\
\hline NASA & National Aeronautical and Space Administration \\
\hline NBSR & National Bureau of Standards Reactor \\
\hline NIST & National Institute of Standards and Technology \\
\hline NNSA & National Nuclear Security Administration \\
\hline NRC & US Nuclear Regulatory Commission \\
\hline $\mathrm{M}^{3}$ & Office of Material Management and Minimization \\
\hline ORNL & Oak Ridge National Laboratory \\
\hline PNNL & Pacific Northwest National Laboratory \\
\hline $\mathrm{R} \& \mathrm{D}$ & research and development \\
\hline RERTR & Reduced Enrichment for Research and Test Reactors \\
\hline RHF & Réacteur à Haut Flux (High Flux Reactor) \\
\hline $\mathrm{SCK} \cdot \mathrm{CEN}$ & Studiecentrum voor Kernenergie - Centre d'Étude de l'Energie Nucléaire \\
\hline SHE & super heavy element \\
\hline
\end{tabular}




\section{ACKNOWLEDGEMENTS}

Thanks are extended to Doug Selby, George Flanagan, and Kevin Smith from Oak Ridge National Laboratory for their review of the document and valuable comments and suggestions. 


\section{INTRODUCTION}

The High Flux Isotope Reactor (HFIR) is a vital national and international resource for neutron science research, production of radioisotopes, and materials irradiation. While HFIR is expected to continue operation for the foreseeable future, interest is growing in understanding future research reactors features, needs, and requirements. To clarify, discuss, and compile these needs from the perspective of Oak Ridge National Laboratory (ORNL) research and development (R\&D) missions, a workshop, titled "Needs and Requirements for Future Research Reactors”, was held at ORNL on May 12, 2015. The workshop engaged ORNL staff that is directly involved in research using HFIR to collect valuable input on the reactor's current and future missions.

The workshop provided an interactive forum for a fruitful exchange of opinions and included a mix of short presentations and open discussions. ORNL staff members made 15 technical presentations based on their experience and areas of expertise, and discussed those capabilities of the HFIR and future research reactors that are essential for their current and future $R \& D$ needs. The workshop was attended by approximately 60 participants from three ORNL directorates. The agenda is included in Appendix A.

This document summarizes the feedback provided by workshop contributors and participants. It also includes information and insights addressing key points that originated from the dialogue started at the workshop. A general overview is provided on the design features and capabilities of high performance research reactors currently in use or under construction worldwide. Recent and ongoing design efforts in the US and internationally are briefly summarized, followed by conclusions and recommendations. 


\section{USER NEEDS AND REQUIREMENTS}

The three key missions of HFIR are neutron scattering, isotope production, and materials irradiation. The needs and requirements for these missions are discussed below based on specific feedback from presenters and participants at the ORNL workshop that was held on May 12, 2015. Achieving all of these individual requests from the three key missions with the same reactor system will be extremely difficult, if feasible. Prioritization of the missions and objectives will be needed for developing a practical and achievable solution. This report presents the key objectives stated for the applications discussed at the workshop, for further consideration.

\subsection{NEUTRON SCATTERING}

Requirements for the neutron scattering applications that rely on a research reactor as a steady state neutron flux source fall into three categories:

- Neutronic environment at the experiment location (neutron flux and flux spectrum, background gamma radiation flux and spectrum);

- Reactor environment at experiment location

o spatial - accommodation of needs related to sample size and instruments settings

o temporal - accommodation of needs related to experiment duration; and

- Instrumentation environment (characteristics and performance of neutron scattering instruments).

The neutronic environment at the experiment location is the primary driver for all neutron scattering experiments. It is significantly affected by the beam transport from the source (reactor core) to the experiment location. Advances in beam optics could be used to enhance the ability to transport and manipulate neutrons from the source to the analyzed sample location.

Critical parameters for both thermal and cold neutron experiments include neutron flux value, signal-tonoise ratio, and time-integrated flux value (i.e., fluence) at the sample location. To address current and envisioned $R \& D$ requirements, the following actions must be taken:

- Increase flux at experiment location by at least one order of magnitude for thermal and cold neutrons.

o A $10^{9} \mathrm{n} / \mathrm{cm}^{2}$ s cold neutron flux at the end of the beam is ideal for imaging (a typical range for cold neutrons is $0.3-5 \mathrm{meV}$ in energy or 4-16 $\AA$ in wavelength).

o An increase in flux, in addition to instrument optimization, is needed to allow for capturing with adequate statistics the conformational changes in biological structures (time scale of $1 \mathrm{~ms}-1 \mathrm{~s}$; length scale of $1-100 \mathrm{~nm}$ ).

o Higher flux rates are needed for better resolution of neutron imaging applied to automotive research areas (static visualization, fluid dynamics). Obtaining statistically significant images in short times (ms) is currently difficult to achieve; $\mu$ s ranges are desired.

o Higher flux rates would be beneficial to R\&D using thermal neutron beams for inelastic scattering and diffraction (a typical range for thermal neutrons in scattering applications is 5-100 meV in energy or 0.9-4 $\AA$ in wavelength).

\section{- Keep signal-to-noise ratio minimal.}

o Epithermal and fast neutron flux components should be as small as possible. 
o Gamma flux at the experiment location should be eliminated or minimized as much as possible.

o Mitigation of signal-to-noise ratio at HFIR is currently not feasible via reconfiguration, shielding, or instruments (the space is limited for reconfiguration of thermal instruments).

\section{- Maximize fluence.}

o Some experiments benefit from increases in both flux and fluence.

o Some experiments could accommodate fluence requirements by either an increase in flux or an increase in reactor cycle duration.

The reactor environment should allow for flexibility on spatial and temporal expansion and/or reconfiguration of experiments. It should accommodate:

- Varying beam size, from small to up to $30 \mathrm{~cm} \times 30 \mathrm{~cm}$, to cover more area with high resolution; a $30 \mathrm{~cm} \times 30 \mathrm{~cm}$ field of view at sample location would be ideal for neutron radiography

- Spectrum variation capabilities

- Large size samples for biological/environmental sciences applications (e.g., for plants instead of seedlings).

Performance for neutron scattering is a function of three independent components' efficacy (Fig. 1):

- neutron source (reactor core and spectrum modifying devices such as a cold source),

- neutrons transmission system (from the generating source to the experiment location), and

- measurement/detecting system (at the experiment location).

Advances in any of these three components are equally important for increasing the overall performance.

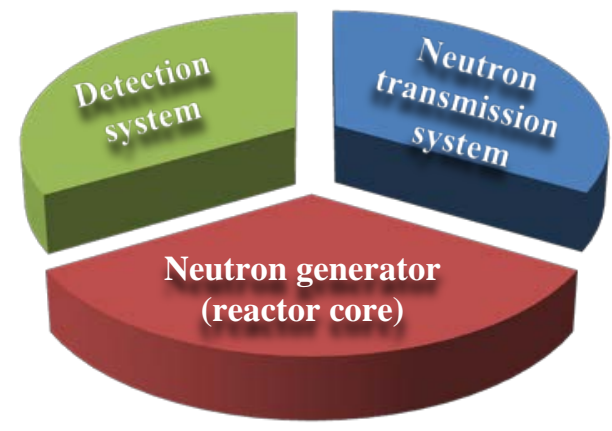

Fig. 1. Drivers of neutron scattering performance.

In addition to the performance and environment needs mentioned above, desired capabilities for a new reactor include:

- at least two cold sources with large areas and high focus to accommodate multiple neutron scattering applications,

- high brightness thermal beams (brightness is a measure of neutron beam intensity, energy and spatial characteristics at the sample location, expressed in $\mathrm{n} / \mathrm{cm}^{2} \mathrm{~s} / \AA \AA$ steradian) and,

- optics systems for thermal beam lines that would allow for expansion and isolation of thermal instruments, 
- $\quad$ special setup stations for certain instruments where setup can occur close to the instrument without impacting beam time, and

- building expansion capabilities to accommodate more beam lines and labs as needed.

\subsection{ISOTOPE PRODUCTION}

The parameter of highest importance for isotope production is the magnitude of the thermal flux, followed by the magnitude of the epithermal flux. Isotope production at ORNL supports a variety of science and engineering applications, such as:

- radioisotopes for industrial applications (e.g., ${ }^{252} \mathrm{Cf},{ }^{75} \mathrm{Se}$ ),

- radioisotopes for medical applications (e.g., ${ }^{225} \mathrm{Ac},{ }^{188} \mathrm{~W}$ ),

- ${ }^{238} \mathrm{Pu}$ for radioisotope thermoelectric generators (RTGs) for National Aeronautical and Space Administration (NASA) applications and national security applications,

- $\quad$ actinide isotopes for super-heavy element (SHE) research (e.g., ${ }^{249} \mathrm{Bk}$, essential for discovery of new element 117),

- radioisotopes for nuclear forensics (e.g., ${ }^{63} \mathrm{Ni}$ ) , and

- heavy-Pu and other actinides isotopes for nuclear security R\&D (e.g., $\left.{ }^{244} \mathrm{Pu}\right)$.

Though specific flux requirements for isotope production vary by isotope, it is essential to retain high values of thermal and epithermal fluxes in order to maintain and enhance capabilities for production of high specific activity radioisotopes or isotopes resulting from multi-neutron capture reactions (e.g., ${ }^{252} \mathrm{Cf}$ ). The specific flux requirements must be assessed in tandem with other key parameters for this mission, including determining the number of total irradiation positions and volumes needed for various specific isotope production needs.

Specific flux value requirements include:

- Minimum thermal flux $>\mathbf{1 . 0} \times \mathbf{1 0}^{15} \mathbf{n} / \mathbf{c m}^{2} \mathbf{s}$. Impacts of thermal fluxes $<10^{15} \mathrm{n} / \mathrm{cm}^{2}$ s include:

0 transuranium element experiments will not be feasible,

o some isotopes cannot be produced (e.g., ${ }^{188} \mathrm{~W}$ ),

o production irradiations would have to be impractically long,

o production of ${ }^{225} \mathrm{Ac}$ would not be feasible, and

0 the legacy mission of ${ }^{252} \mathrm{Cf}$ production cannot be maintained.

- Desired thermal flux $>2.5 \times 10^{15} \mathbf{n} / \mathbf{c m}^{2} \mathrm{~s}$, for improved efficiency of existing capabilities and to open new R\&D possibilities. Impacts include:

o better schedule (shorter irradiation times), leading to improved isotope yields for current production capabilities,

o improved production of heavy-Pu isotopes, which are nuclear security priority isotopes used as nonfissile surrogates to enable new analysis/stockpile functions,

o improved production of medical radioisotopes currently produced as part of the National Isotope Program $\left({ }^{225} \mathrm{Ac},{ }^{188} \mathrm{~W},{ }^{177} \mathrm{Lu}\right)$, and

o basic science capabilities continued for production of higher actinides essential for SHE research.

Requirements related to the reactor environment (sample irradiation capabilities and transfer/processing of irradiated samples from irradiation location to manipulation/detecting location) are generally similar for isotope production, neutron activation analysis (NAA), and trace element forensics, and include: 
- continuous access to the core while the reactor is operating (i.e. via hydraulic tubes for production of short-lived isotopes and reduction of unwanted byproducts),

- fast pneumatic transfer systems for sample transfer from irradiation site to receiving/detector station (for NAA),

- online access to the processing facility - availability of onsite hot cell(s) in the reactor building, for target manipulation, measurements and disassembly,

- shielded receiving station for irradiated NAA samples (major need for NAA),

- proximity of detection system to neutron source and handling station,

- both large and small sample irradiation capabilities for NAA - largest sample size currently $1 \mathrm{ml}$, International Atomic Energy Agency (IAEA) sample size $10 \times 10 \mathrm{~mm}$,

- neutron spectrum filtering capabilities to selectively increase/decrease the yield of specific isotopes.

\subsection{MATERIAL IRRADIATION}

Material irradiation covers multiple application areas in nuclear science and technology, including development and testing of new materials for fusion science and materials for existing and advanced reactor systems, as well as testing of existing or new fuel systems.

The neutronic environment at the experiment location that is desirable for materials irradiation includes:

- Fast neutron flux (energy $>0.1 \mathrm{MeV}$ ) in the range $10^{12}-10^{15} \mathbf{n} / \mathbf{c m}^{2} \mathbf{s}$ for investigating radiation damage and ensure large damage rates

o currently $\sim 12$ displacements per atom (dpa)/yr

o more than 20-30 dpa/yr desired,

- Thermal neutron flux $\sim 2.5 \times 10^{15} \mathbf{n} / \mathbf{c m}^{2}$ s for experiments examining transmutation effects,

- Fast-to-thermal flux ratio $>0.5$ to avoid activation for radiation damage studies, and

- Limited nuclear heating rates (< HFIR's $45 \mathrm{~W} / \mathrm{g}$ in stainless steel; would vary depending on application).

The reactor environment at the experiment location should permit/provide:

- “large” experimental volume > current HFIR target rod volume,

- in situ instrumentation and monitoring (of temperature, heating),

- improved irradiation capabilities for very low fluence via hydraulic tubes,

- adaptable experiment configurations (noncylindrical geometry) to allow for more creative experiment designs,

- flexible access to instrumentation, and

- prompt gamma irradiation capabilities (nonexistent at this time) for accelerated radiation damage studies. 


\section{GENERAL CONSIDERATIONS - LOOKING TOWARD FUTURE RESEARCH REACTORS}

The ORNL workshop in May 2015 started a dialogue to discuss existing performance and facility resources and to determine what is needed and desired from a future steady-state neutron source. Moreover, it opened a discussion on possible paths forward once the goal is clearly framed.

A high flux research reactor as a continuous neutron source is absolutely necessary to maintain ORNL's unparalleled capabilities for R\&D involving neutron scattering experiments. While a spallation source provides better neutron capabilities for $\mathrm{R} \& \mathrm{D}$ on atomic and picoseconds scales (sharpest pulses, largest dynamic range, optimized for cold neutrons with high peak brightness or/and high-wavelength resolution across the neutron spectrum), a research reactor is ideal for applications on macromolecular and microseconds scales (highest fluxes, optimized for high time-averaged brightness). Complementarity across all ORNL neutron sources could provide opportunities for instrument optimization.

A high flux research reactor is absolutely necessary to ensure that ORNL remains the world's most reliable source of unique radioisotopes for commercial use and medical applications (e.g. ${ }^{252} \mathrm{Cf},{ }^{227} \mathrm{Ac}$, ${ }^{188} \mathrm{~W}$ ), as well as a source of actinides of strategic importance for national security applications and special national R\&D programs (e.g., ${ }^{238} \mathrm{Pu}$ ). A high flux research reactor is essential for ORNL to remain at the forefront of super-heavy element research (e.g., production of ${ }^{249} \mathrm{Bk},{ }^{254} \mathrm{Es}$ ) and R\&D on medical radioisotopes.

All workshop participants concurred that targeting a single-mission research reactor would be extremely limiting for current and future R\&D needs. Conversely, a facility that would equally meet at an ideal level all R\&D needs (neutron scattering, isotope production, and material irradiation) would be significantly complex, extremely challenging to design and build, with substantial increases in building and operation/maintenance costs.

Compromises and negotiating objectives are anticipated when planning a new research reactor. Various suggestions were made, one of which proposed a HFIR-like reactor with two primary missions: isotope production and neutron scattering. By meeting the needs of these two primary missions, the reactor would implicitly provide a neutronic environment of reasonable adequacy for material irradiation applications. A different suggestion was made to construct a cluster of small research reactors with consolidated operation and shared support systems, with each reactor targeting a specific application/mission.

All participants concurred that ORNL's forefront position must be maintained and that lessons learned from ORNL's long history of hosting 13 reactors and implementation of related design efforts should be taken into account when planning new research reactor systems.

The Advanced Neutron Source (ANS) project conducted at ORNL during 1985-1995 was the last major research reactor design effort in the US. The ANS conceptual design report provides significant information for future reactor design efforts [1]. Even though the ANS design provided a state-of-the-art neutron source, the project was cancelled due to high associated costs and US international commitments to eliminate highly-enriched uranium (HEU) from its research reactor facilities. The ANS effort showed that planning for a new reactor is a long-term endeavor, and the time required to establish a design team 
must be taken into consideration. The ANS project included a 10-year preconceptual/conceptual design phase, starting with a small effort that grew over the project's lifetime. Fortunately, some of the ANS participants continue to work at ORNL and can provide valuable feedback and contributions. The ANS project demonstrated that strong support from the user community is important but not sufficient when planning a new research reactor and that support from government agencies, private investors, and the general public is also needed.

Workshop participants discussed various approaches for funding a new design and construction effort. One idea was to identify the government agencies and private investors for which the planned reactor's capabilities would be essential for their R\&D and/or production needs. These government/private agencies could be engaged during early planning to help ensure financial support for future building and operation. Planning for HFIR in the late 1950s showed that consideration of particular needs of the agencies willing to support the effort is one of the keys to a successful outcome. In 1957-1958, Alvin Weinberg directed ORNL’s Ultra High Flux Research Reactors program. This program included workshops and seminars engaging the laboratory community, and it provided the foundation [2] for developing and later building HFIR, which achieved its first critical state in August 1965.

Operation and costs considerations should be included during planning and preconceptual design stages. Designing the operation to be as simple as possible will ensure low operation and maintenance costs and facilitate better control of safety requirements. Low operation and maintenance costs and minimal preventive maintenance time will make longer annual operation times possible. This in turn will benefit all users’ applications. Designing a reactor with longer cycle length (current HFIR cycle is 24-26 days) will help reducing operation costs. Minimizing fuel costs will also be an important factor, as current fuel cost represents $\sim 20 \%$ of HFIR's annual operation costs.

Facility integration and zoning must also be considered in the initial design phase. The initial phase should consider integration of a cold source (or cold sources) and associated guide hall, as well as integration of hot cells capabilities. The initial design planning should also ensure that potential expansion (i.e., additional guide halls, larger experiments and detecting systems, etc.) will be possible once the facility has been built.

A key limitation at this time is the lack of qualified low-enriched uranium (LEU) fuel with very high density, which is essential to building a research reactor core with a high power density and high flux. Currently, HFIR operates with $\mathrm{HEU} \mathrm{U}_{3} \mathrm{O}_{8} / \mathrm{Al}$ dispersion fuel, with 93.2wt $\%{ }^{235} \mathrm{U} / \mathrm{U}$ enrichment, and density of $\sim 1.1 \mathrm{gU} / \mathrm{cm}^{3}$ fuel. The ANS design considered an HEU $\left(93.2 \mathrm{wt} \%{ }^{235} \mathrm{U} / \mathrm{U}\right) \mathrm{U}_{3} \mathrm{Si}_{2} / \mathrm{Al}$ dispersion fuel with $3.2 \mathrm{gU} / \mathrm{cm}^{3}$ density. 


\section{OVERVIEW OF CAPABILITIES WORLDWIDE}

There are 45 research reactors worldwide [3] operating at thermal power $>10 \mathrm{MW}, 5$ of which are located in the US. Fourteen of these reactors operate at $>50 \mathrm{MW}$ and are located as follows: three in North America, three in Western Europe, four in Russia, and four in Asia.

A summary of HFIR peer-level research reactors operating worldwide is presented in Table 1 . The table includes 13 reactors ranked from the highest to the lowest magnitude of reported thermal flux. Eleven of these 13 reactors report maximum thermal fluxes $>5.0 \times 10^{14} \mathrm{n} / \mathrm{cm}^{2} \mathrm{~s}$; the other two report both high thermal and fast fluxes and are recognized as leading experimental facilities. Of these reactors, four are in the US, three are in the European Union (France, Belgium, Germany), three are in Russia, two are in China, and one is in Kazakhstan. Most of these reactors are old, with 11 of them started in the 1960s and 1970s. The Forschungs-Neutronenquelle Heinz Maier-Leibnitz (FRM II) reactor in Germany and the China Advanced Research Reactor (CARR) are the only two reactors from this group that were started after 2000. Ten of the reactors listed use light water as coolant. The French Réacteur à Haut Flux (High Flux Reactor) (RHF) and the National Bureau of Standards Reactor (NBSR) at the National Institute of Standards and Technology (NIST) in the US both use heavy water as coolant. The Russian BOR-60, a fast reactor, uses liquid sodium as coolant. The reflector used in the 12 thermal reactors listed in Table 1 consists of either beryllium or heavy water.

Only three of the 13 reactors listed in Table 1 use LEU fuel. Two are in China, the CARR and the High Flux Engineering Test Reactor (HFETR) (using $\mathrm{U}_{3} \mathrm{Si}_{2}-\mathrm{Al}$ fuel). The third one is the Kazakhstan's research reactor, which is currently under testing with an $\mathrm{LEU} \mathrm{UO}_{2}$-Al fuel core.

Three of the 10 reactors using HEU are Russian: SM-3, MIR.M1, and BOR-60 [4]. The BOR-60 and SM3 reactors are planned to be operated until $\sim 2020$, when their current operating licenses expire. The LEU conversion of MIR.M1 has been investigated under a Rosatom - National Nuclear Security Administration (NNSA) Implementing Agreement (December 2010) to conduct feasibility studies for conversion to LEU fuel of six Russian research reactors [5]. The HFIR peer-level non-Russian reactors operating with HEU that are located in US and Western Europe are actively engaged in LEU conversion feasibility studies. These studies consider high density uranium molybdenum (U-Mo) fuel in alloy or dispersion form. A U-Mo alloy fuel $\left(\sim 15 \mathrm{gU} / \mathrm{cm}^{3}\right.$ fuel) is being developed at the Idaho National Laboratory (INL) under the NNSA reactor conversion program. A U-Mo dispersion fuel $\left(\sim 8 \mathrm{gU} / \mathrm{cm}^{3}\right.$ fuel) is being developed in Europe under the LEONIDAS and HERACLES projects, with participants from Studiecentrum voor Kernenergie - Centre d'Étude de l'Energie Nucléaire (SCK•CEN) in Belgium, and Institut Laue-Langevin (ILL), Commisariat à l'Énergie Atomique (CEA), and Areva's subsidiary Compagnie pour l'Étude et la Réalisation de Combustibles Atomiques (Company for the Study of Atomic Fuel Creation) (CERCA) in France. Under HERACLES, a U-Mo dispersion fuel with fuel particle coatings is being developed [5].

There are only three high flux research reactors under construction worldwide (see Table 2). One is the Jules Horowitz Material Testing Reactor (JHR), under construction in France and designed to be the forefront European nuclear experimental facility of the next decade [6]. Construction of JHR started in 2009 [6] and is ongoing at the CEA center in Cadarache [7,8]. This reactor was designed to reach peak fast and thermal fluxes of $1.0 \times 10^{15}$ and $5.5 \times 10^{14} \mathrm{n} / \mathrm{cm}^{2} \mathrm{~s}$. It was planned to reach its first critical state in 2014, but startup has been delayed. The reactor is planned to use $\mathrm{U}_{3} \mathrm{Si}_{2}\left(\mathrm{HEU}, 27 \mathrm{wt} \%{ }^{235} \mathrm{U} / \mathrm{U}, 4.8 \mathrm{~g}\right.$ 
$\mathrm{U} / \mathrm{cm}^{3}$ ) as startup fuel and to operate with LEU U-Mo dispersion fuel $\left(8 \mathrm{~g} \mathrm{U} / \mathrm{cm}^{3}\right)$. However, the U-Mo LEU fuel is still undergoing qualification testing and is not yet available.

The PIK reactor, which is located in St. Petersburg, Russia, aims to be the most powerful thermal research reactor, with estimated peak thermal fluxes higher than $10^{15} \mathrm{n} / \mathrm{cm}^{2} \mathrm{~s}$ in both the core and the reflector [9,10]. Designed to operate at $100 \mathrm{MW}$, PIK reached its first critical state in 2011. The construction was completed in 2013, with licensing of facility planned for 2015, and operation at full power scheduled for 2018 [10]. The PIK uses HEU (90wt $\%{ }^{235} \mathrm{U} / \mathrm{U}$ ) fuel that consists of enriched $\mathrm{UO}_{2}$ dispersed in a Cu-Be matrix. It is unlikely that this reactor will ever be converted to LEU; scoping studies indicate that reactor performance will not be maintained if converted using existing LEU fuel [11].

The MBIR reactor, located in Dimitrovgrad, Russia, is a multipurpose, sodium-cooled, fast research reactor with an estimated peak flux of $5.5 \times 10^{15} \mathrm{n} / \mathrm{cm}^{2} \mathrm{~s}$. It is designed for an operating power of 150 MW. The considered fuel is a Russian variant of mixed oxide (MOX) fuel - a mixture of MOX granulated (93 wt\%) and uranium metal powder (7 wt\%) [12]. The construction license for this facility was issued in May 2015, and construction officially started in September 2015. The MBIR is planned to become operational in 2020, in time to replace BOR-60, the world's only fast research reactor in operation. 
Table 1. Main characteristics [4] of high performance research reactors

\begin{tabular}{|c|c|c|c|c|c|c|c|c|c|c|}
\hline \# & Name & Location & Design features & $\begin{array}{c}\text { Year } \\
\text { first } \\
\text { critical }\end{array}$ & $\begin{array}{c}\text { Thermal } \\
\text { power } \\
\text { (MW) }\end{array}$ & $\begin{array}{l}\text { Fuel } \\
\text { type }\end{array}$ & Coolant & Reflector & $\begin{array}{c}\text { Peak } \\
\text { thermal flux } \\
\left(\mathbf{n} / \mathbf{c m}^{2} \mathbf{s}\right)\end{array}$ & $\begin{array}{c}\text { Peak } \\
\text { fast flux } \\
\left(\mathrm{n} / \mathrm{cm}^{2} \mathrm{~s}\right)\end{array}$ \\
\hline 1 & SM-3 & Dimitrovgrad, Russia & $\begin{array}{l}\text { Pressure vessel, } \\
\text { flux trap }\end{array}$ & 1961 & 100 & HEU & $\mathrm{H}_{2} \mathrm{O}$ & $\mathrm{Be}$ & $5.0 \times 10^{15}$ & $2.0 \times 10^{15}$ \\
\hline 2 & HFIR & ORNL, USA & Tank, flux trap & 1965 & $85^{a}$ & HEU & $\mathrm{H}_{2} \mathrm{O}$ & $\mathrm{Be}$ & $2.5 \times 10^{15}$ & $1.0 \times 10^{15}$ \\
\hline 3 & RHF & ILL, France & Tank, flux trap & 1969 & 58.3 & HEU & $\mathrm{D}_{2} \mathrm{O}$ & $\mathrm{D}_{2} \mathrm{O}$ & $1.5 \times 10^{15}$ & \\
\hline 4 & BR2 & SCK•CEN, Belgium & Tank, MTR & 1962 & 100 & HEU & $\mathrm{H}_{2} \mathrm{O}$ & $\mathrm{Be}$ & $1.0 \times 10^{15}$ & $7.0 \times 10^{14}$ \\
\hline 5 & ATR & INL, USA & Tank, MTR & 1967 & 250 & HEU & $\mathrm{H}_{2} \mathrm{O}$ & $\mathrm{Be}$ & $8.5 \times 10^{14}$ & $1.8 \times 10^{14}$ \\
\hline 6 & FRM II & Munich, Germany & Pool & 2005 & 20 & HEU & $\mathrm{H}_{2} \mathrm{O}$ & $\mathrm{D}_{2} \mathrm{O}$ & $8.0 \times 10^{14}$ & $5.0 \times 10^{14}$ \\
\hline 7 & IVG.1M & $\begin{array}{l}\text { Kurchatov City, } \\
\text { Kazakhstan }\end{array}$ & Tank & $1971^{b}$ & 35 & $\mathrm{LEU}^{b}$ & $\mathrm{H}_{2} \mathrm{O}$ & $\mathrm{Be}$ & $8.0 \times 10^{14}$ & $1.7 \times 10^{14}$ \\
\hline 8 & CARR & Beijing, China & $\begin{array}{l}\text { Tank in pool, } \\
\text { flux trap }\end{array}$ & 2010 & 60 & LEU & $\mathrm{H}_{2} \mathrm{O}$ & $\mathrm{D}_{2} \mathrm{O}$ & $8.0 \times 10^{14}$ & $6.0 \times 10^{14}$ \\
\hline 9 & HFETR & Chengdu, China & Tank & $1979^{c}$ & 125 & $\mathrm{LEU}^{c}$ & $\mathrm{H}_{2} \mathrm{O}$ & $\mathrm{Be}$ & $6.2 \times 10^{14}$ & $1.7 \times 10^{15}$ \\
\hline 10 & MURR & $\begin{array}{l}\text { University of Missouri, } \\
\text { Columbia, USA }\end{array}$ & $\begin{array}{l}\text { Tank in pool, } \\
\text { flux trap }\end{array}$ & 1966 & 10 & HEU & $\mathrm{H}_{2} \mathrm{O}$ & $\begin{array}{c}\text { Be } \\
\text { Graphite }\end{array}$ & $6.0 \times 10^{14}$ & $1.0 \times 10^{14}$ \\
\hline 11 & MIR.M1 & Dimitrovgrad, Russia & Loop type, pool & 1967 & 100 & HEU & $\mathrm{H}_{2} \mathrm{O}$ & $\mathrm{Be}$ & $5.0 \times 10^{14}$ & $1.0 \times 10^{14}$ \\
\hline 12 & NBSR & NIST, USA & Tank & 1967 & 20 & HEU & $\mathrm{D}_{2} \mathrm{O}$ & $\mathrm{D}_{2} \mathrm{O}$ & $4.0 \times 10^{14}$ & $2.0 \times 10^{14}$ \\
\hline 13 & BOR-60 & Dimitrovgrad, Russia & Fast breeder & 1969 & 60 & HEU & $\begin{array}{l}\text { Liquid } \\
\mathrm{Na}\end{array}$ & $\begin{array}{l}\text { Stainless } \\
\text { steel }\end{array}$ & $2.0 \times 10^{14}$ & $3.7 \times 10^{15}$ \\
\hline
\end{tabular}


Table 2. Main characteristics of JHR, PIK, and MBIR research reactors

\begin{tabular}{llll}
\hline & JHR, France & PIK, Russia & MBIR, Russia \\
\hline Reactor type & Tank in pool & Tank & Fast \\
Thermal power (MW) & 100 & 100 & 150 \\
Reflector & Beryllium & Heavy water & Stainless steel \\
Coolant & Light water & Light water & Liquid sodium \\
Fuel & HEU, LEU ${ }^{a}$ & HEU $^{\boldsymbol{b}}$ & MOX $^{c}$ \\
Peak thermal flux (n/cm & $5.5 \times 10^{14 \boldsymbol{a}}$ & $5.0 \times 10^{15 \boldsymbol{b}}$ & N/A \\
Peak fast flux (n/cm $\left.{ }^{2} \mathrm{~s}\right)$ & $1.0 \times 10^{15 \boldsymbol{a}}$ & $8.0 \times 10^{14 \boldsymbol{b}}$ & $5.5 \times 10^{15 c}$ \\
\hline
\end{tabular}

$a$ Source: Ref. 8.

${ }^{b}$ Source: Ref. 10

${ }^{c}$ Source: Ref. 12. 


\section{RECENT DESIGN STUDIES}

\subsection{LEU CONVERSION}

Through programs directed at reducing the use of weapons-grade nuclear materials in civilian applications, the NNSA has supported the conversion of domestic and international research reactors from using HEU to LEU since 1978. In 2004, the reactor conversion was incorporated as one of the main pillars of HEU minimization [5] in the Global Threat Reduction Initiative (GTRI) program. This program was formerly known as the Reduced Enrichment for Research and Test Reactors (RERTR). Currently, the LEU conversion effort is overseen by the NNSA Office of Material Management and Minimization $\left(\mathrm{M}^{3}\right)$.

Under NNSA support, feasibility studies are under way to study the conversion of the US high performance research reactors (HPRRs) and the US-supplied high flux European research reactors still operating with HEU fuel. The main limitation in this endeavor is the lack of an appropriate, robust, licensed LEU fuel. The LEU fuel would also need to allow a safe, reliable, affordable conversion with no significant impact on the reactor's performance or its ability to perform its scientific missions, and with no major changes to reactor infrastructure $[5,13]$. The five US HPPRs operating with HEU fuel and undergoing LEU conversion feasibility studies are: the Massachusetts Institute of Technology Reactor (MITR), MURR at University of Missouri, NBSR at NIST, the Advanced Test Reactor (ATR) at INL, and HFIR at ORNL. The high flux European reactors operating with HEU fuel are: BR-2 at SCK•CEN in Belgium, RHF at ILL in France, and FRM-II in Munich, Germany.

Conversion of these reactors is challenging because they would all need a high or very high density LEU fuel to perform adequately at a very high power density and burnup while at the same time meeting the conversion program requirements. The current LEU fuel under consideration by NNSA for conversion of all US HPRRs is a U-Mo foil fuel ( $15 \mathrm{~g} \mathrm{U} / \mathrm{cm}^{3}$ fuel), which is under development/fabrication. The European reactors are considering a U-Mo dispersion fuel $\left(\sim 8 \mathrm{~g} \mathrm{U} / \mathrm{cm}^{3}\right)$; activities for qualification of this fuel are ongoing.

Feasibility studies for HFIR conversion [14] have analyzed optimizing or eliminating those features of a preliminary HFIR LEU design that were identified as problematic for manufacturing. Preliminary performance and safety analyses indicate that HFIR could be converted and maintain its current performance if the LEU fuel is qualified to HFIR conditions, manufactured to HFIR specifications, and demonstrated to be reliable and affordable [15]. In addition, to maintain its current performance after converting to LEU, while meeting the constraints required by the NNSA conversion program, HFIR would need to increase the operating power from the current $85 \mathrm{MW}$ value to $100 \mathrm{MW}$.

Development of a qualified, commercially available, suitable LEU fuel [14] for US HPRRs conversion is a challenging, long-term endeavor. The U-Mo fuel development effort is led by INL, while the fuel fabrication effort is led by Pacific Northwest National Laboratory (PNNL). U-Mo foils and mini-plates have been undergoing irradiation testing since 2006. A fuel qualification report for the U-Mo foil fuel is planned to be submitted to the US Nuclear Regulatory Commission (NRC) in 2023 [16]. Special fuel fabrication or fuel qualification efforts may be required for reactors with specific fuel designs [5]. Irradiation experiments of a HFIR LEU full-size plate are planned to be conducted in the BR-2 reactor in Belgium in 2023-2026 [17]. 


\subsection{DESIGN EFFORTS FOR FUTURE RESEARCH REACTORS}

There are only three facilities under construction internationally: the Russian PIK, which is designed for HEU fuel; the French JHR, which is designed to work with LEU fuel; and, the Russian MBIR, which is designed to use MOX fuel. JHR was planned to start in 2014, but it has been delayed by a redesign effort to address additional regulatory requirements following the 2011 Fukushima event in Japan, as well as by setbacks in certification of the LEU fuel (U-Mo dispersion, $19.7 \mathrm{wt} \%{ }^{235} \mathrm{U} / \mathrm{U}, 8 \mathrm{U} / \mathrm{cm}^{3}$ ) that was used as the basis for the initial design. At this time, the first JHR core is planned to use HEU fuel $\left(\mathrm{U}_{3} \mathrm{Si}_{2}, 27 \mathrm{wt} \%\right.$ ${ }^{235} \mathrm{U} / \mathrm{U}, 4.8 \mathrm{~g} \mathrm{U} / \mathrm{cm}^{3}$ ) that is commercially available; the LEU U-Mo dispersion fuel is still under qualification testing.

Laboratory-directed research efforts have been under way at US national laboratories operating HPRRs (INL, NIST) to investigate potential research reactor configurations as replacements of their current facilities. These efforts are concurrent with the LEU conversion studies and share some of the goals and challenges, but they also exhibit some differences in objectives and requirements. The LEU conversion is a redesign effort, with nonlinear multi-objectives, as well as multi-constraints to optimize an existing system. The search space for this optimization is limited, with no major changes in reactor structures or equipment, while performance requirements aim to ensure that the ability to perform the scientific mission is not significantly impacted [5]. The scoping studies of new configurations are addressing a less constrained design space, although availability of a high density LEU fuel remains the major challenge. New configurations are targeting major improvements in performance, while updates to existing systems are more limited in the LEU conversion studies.

The INL design studies focused on concepts that could support the current mission of ATR as the largest US large-scale fuels and materials irradiation capability. The recent research program [18] was a continuation of similar efforts made in the 1990s (when HEU fuel was considered). This recent program was intended to address the needs compiled from a survey and a meeting held in 2012 at INL with potential stakeholders [18]. The investigated concept, named MATRIX, aimed to achieve the primary mission of materials irradiation. This concept involves using cylindrical fuel assemblies of plate fuel arranged in a cylindrical core rack that uses light water as the primary coolant and heavy water as the reflector. The design has similarities with the French JHR design. The MATRIX concept was evaluated for two options for the LEU fuel: a currently qualified $\mathrm{U}_{3} \mathrm{Si}_{2}$ dispersion fuel $\left(4.8 \mathrm{~g} \mathrm{U} / \mathrm{cm}^{3}\right)$ and a U-Mo alloy fuel $\left(15.2 \mathrm{~g} \mathrm{U} / \mathrm{cm}^{3}\right)$ as considered by the NNSA LEU conversion program. Only the U-Mo fuel was determined as viable for this concept. Additional evaluations are planned [18] for other high density fuels.

The primary objective of the NIST design effort was to develop a single-mission reactor concept to optimize the quality of cold neutron beams [19]. The proposed concept departs from the traditional compact core design, with fuel at the center of the reactor surrounded by reflector, by featuring a horizontally split core configuration in a heavy water tank, with the cold neutron source being located at the center of the split core. Results of the scoping studies indicate that the cold neutron performance of the new core is better than that of the current NBSR and superior to other similar facilities worldwide. The LEU fuel considered in these studies was $\mathrm{U}_{3} \mathrm{Si}_{2} / \mathrm{Al}$ dispersion $\left(4.8 \mathrm{~g} \mathrm{U} / \mathrm{cm}^{3}\right)$, a fuel certified by NRC for research reactors. 


\section{CONCLUSIONS AND RECOMMENDATIONS}

To clarify and discuss needs and requirements for future research reactor systems from the perspective of ORNL R\&D missions, a workshop, "Needs and Requirements for Future Research Reactors," was held at ORNL on May 12, 2015. The workshop facilitated a dialogue on this topic for staff members currently involved in research using HFIR who can provide valuable input on current and future missions. Through technical presentations and lively exchange of opinions, participants discussed which capabilities of HFIR and future research reactors are essential for $R \& D$ current and future needs. Based on the discussion, recommendations for investigating the enhancement of HFIR and a new ORNL research reactor were developed.

\subsection{SUMMARY OF USER REQUIREMENTS}

User requirements for neutron flux performance are summarized as follows:

- Neutron scattering

- increase flux at experiment location (on sample) by at least one order of magnitude compared to current values,

- $\quad$ keep signal-to-noise ratio minimal, and

- maximize fluence (by increasing flux or reactor cycle length or both).

- Isotope production

- increase thermal flux to $>2.5 \times 10^{15} \mathrm{n} / \mathrm{cm}^{2} \mathrm{~s}$ to improve efficiency of existing capabilities and to open new R\&D possibilities and opportunities, and

- ensure a minimum thermal flux of $1.0 \times 10^{15} \mathrm{n} / \mathrm{cm}^{2} \mathrm{~s}$; below this threshold, the legacy mission of ${ }^{252} \mathrm{Cf}$ production cannot be maintained, production of ${ }^{225} \mathrm{Ac}$ would not be feasible, and isotope production efficiency will decrease to impractical level.

- Material irradiation

- ensure fast flux in the $10^{12}-10^{15} \mathrm{n} / \mathrm{cm}^{2}$ s range and damage rates of 20-30 dpa/yr, and

- $\quad$ keep a fast-to-thermal flux ratio $>0.5$ at the experiment location.

Although some of the needs on neutron flux values discussed above could be mitigated through beam or instrument improvements, depending on the application of interest, ensuring that flux values are kept at least at the current HFIR levels was considered a minimum requirement.

It was recognized that HFIR's performance is excellent and by improving instruments and increasing the number of operating days per year would go a long way towards supporting the future science needs identified above.

\subsection{FEEDBACK ON STRATEGY FOR A NEW ORNL RESEARCH REACTOR}

Feedback on building a new ORNL research reactor included:

- A high flux research reactor as a continuous neutron source is absolutely essential to

- maintain ORNL's unparalleled capabilities for R\&D involving neutron scattering experiments,

- ensure that ORNL remains the world's most reliable source of unique radioisotopes for commercial use and medical applications, and continues its engagement at the forefront of superheavy element research, and

- preserve ORNL capabilities for material irradiation R\&D. 
- Any planning should account for ongoing and planned international developments to ensure that ORNL's forefront position is maintained in the future.

- Zoning and integration of the facility building as well as capability for potential expansion after building's completion must be included in the initial design planning.

- Designing the operation to be as simple as possible and minimizing preventive maintenance time will reduce operation and maintenance costs and will facilitate better control of safety requirements.

- Cost considerations should be included at the initial design level. Low operation and maintenance costs will make longer annual operation times possible, benefiting all users' applications.

- Planning a multiple mission facility with the primary and secondary missions clearly defined will ensure that overall R\&D needs are adequately addressed.

- Strong user support and financial commitment of government agencies and/or private institutions with relevant R\&D needs are key components for a successful endeavor.

When developing a strategy for a future research reactor, ORNL will benefit from lessons learned from existing or planned construction efforts worldwide, as well as from domestic and international efforts that target design of new systems or refitting of existing systems. In conformity with the long-standing U.S policy and steady support to minimize and eliminate the use of HEU in civilian applications domestically and worldwide, a new research reactor design should consider an LEU fuel.

Ultimately, the goal is to provide enduring, foundational capabilities that are essential for ORNL to address big science questions and to work on what is important to the nation [20]. Thinking ahead, keeping pace with attempts at other US laboratories, and maintaining its worldwide leadership role, ORNL should begin investing in systematic efforts to look at next generation research reactor systems.

\subsection{RECOMMENDATIONS}

Specific recommendations include:

1) The HFIR offers world-class performance, presents no technical life-limiting issues for approximately five more decades, and is costly to replace. Therefore, research should focus on maximizing the scientific value of HFIR through:

- Expand research on advanced instrumentation and beam guide technology to improve performance at the measurement location and potentially reduce reactor flux needs for neutron scattering applications;

- Expand research on isotope production technologies to optimize and potentially minimize reactor flux needs for isotope production and neutron activation analysis applications;

- Expand research on materials irradiation instrumentation to provide more, lower-cost data for irradiations;

- Investigate the ability to add new capabilities and features, including a second cold source, expanded thermal guides, and enhanced irradiation capabilities.

- Investigate the ability to increase the number of operating cycles per year and develop other operational improvements, to maximize availability and integrated neutron irradiation time. 
2) Begin a preliminary design effort at ORNL to identify reactor concepts to accomplish the specific ORNL needs and requirements outlined in this report, for a research reactor as a steady neutron source. Because the design and build of a new facility is a long term effort that may take over 10 years, this period could be shortened if a set of adequate reactor concepts would have been already identified and preliminarily studied when opportunities would arise to actively initiate a long term endeavor.

3) Continue development of high-density LEU fuels and advanced fuel systems for use in HFIR to ensure that options to HEU become viable and to support future research reactor development.

4) Initiate international collaborations with institutions having recent or ongoing experience in developing new, high performance research reactor facilities. 


\section{REFERENCES}

1. D. Selby et al., "The Advanced Neutron Source Research and Development Plan,” ORNL/TM12249/R1, Oak Ridge National Laboratory (1995). http://www.osti.gov/scitech/servlets/purl/204251

2. J. A. Lane et al., "Ultra high flux research reactors," ORNL/CF-58-7-117, Oak Ridge National Laboratory (1958). http://www.osti.gov/scitech/biblio/4301543

3. Research Reactor Database, International Energy Agency, http://nucleus.iaea.org/RRDB/RR/ReactorSearch.aspx?rf=1

4. N. Arkhangelsky and A. Izhutov, "Capabilities and Capacities of RIAR Research Reactors," presentation at IAEA, Vienna, Austria (2013).

5. J. Roglans, “GTRI reactor conversion program scope and status,” presentation at the National Academy of Sciences, Washington, DC (2014). http://dels.nas.edu/resources/static-assets/nrsb/miscellaneous/Roglans.pdf

6. G. Bignan, "The Jules Horowitz Reactor: a new high performance European MTR open to international community," 13th Meeting of the International Group on Research Reactors IGORR13-TRTR, Knoxville, TN (2010). http://www.igorr.com/home/liblocal/docs/Proceeding/meeting\%2013/session\%201/BIGNAN.pdf

7. P. Console Camprini, M. Sumini, C. Gonnier, B. Pouchin, P. Sireta, S. Bourdon, "Shutdown transients analysis for reflector devices power calculations in Jules Horowitz Material Testing Reactor (JHR),” PHYSOR 2014, Japan (2014).

8. J. Estrade, G. Bignan, X. Bravo, “The Jules Horowitz Reactor: a new high performance MTR working as an international user facility in support to nuclear industry, public bodies, and research institutes,” European Research Reactor Conference, RRFM 2015, Bucharest, Romania (2015).

9. Y. V. Petrov, A. N. Erykalov, and M. S. Onegin, “The fuel cycle of reactor PIK,” RERTR 2002, Bariloche, Argentina (2002)

10. M. S. Onegin, "Investigation of the possibilities of heavy actinide isotopes production in highflux reactor PIK,” presentation at the Super Heavy Elements Symposium, SHE-2015, Texas A\&M University, TX, USA (2015).

11. A. S. Diakov, "Prospects for Conversion of HEU-Fueled Research Reactors in Russia," Science \& Global Security, 22, no. 3, (2014): 166-187.

12. A. Tuzov, “MBIR International Research Center: Current Progress and Prospects,” Proceedings of International Group of Research Reactors (IGORR) Conference, Bariloche, Argentina (November 2014).

13. J. Stevens, “Objectives and Constraints for Research Reactor Conversion Design: Assessing Alternatives,” presentation at the National Academy of Sciences Review Meeting, Oak Ridge, TN (June 2015). (http://nassites.org/dels/files/2015/08/02_STEVENS_Objectives_and_Constraints_for_RR_Conversion_De sign_Assessing_Alternatives_150624.pdf)

14. D. G. Renfro, D. C. Chandler, D. H. Cook, G. Ilas, P. Jain, and J. Valentine, "Preliminary Evaluation of Alternate Designs for HFIR Low-enriched Uranium Fuel,” ORNL/TM-2014/154, Oak Ridge National Laboratory (October 2014). 
15. D. Renfro, B. Betzler, D. Chandler, D. Cook, J. Freels, F. Griffin, G. Ilas, P. Jain, G. Kirk, C. McAmis, T. Muth, D. Pinkston, E. Popov, E. Sunny, and J. Valentine, "Progress Toward LEU Conversion of the High Flux Isotope Reactor,” presentation at the National Academy of Sciences Committee Review, Oak Ride, TN (June 2015). http://nas-sites.org/dels/files/2015/08/04_RENFRO_HFIR-LEU-CONVERSION-NASREVIEW-6-24-15-DGR-6-15-15.pdf.

16. Barry Rabin, “USHPRR Base Fuel Qualification Plan and Requirements,” presentation at the National Academy of Sciences Review Meeting, Idaho Falls, ID (February 2015).

http://dels.nas.edu/resources/static-assets/nrsb/miscellaneous/U-Mo-Fuel-Dev/rabin.pdf

17. M. Itamura,’HFIR Fuel Development Effort,” presentation at the National Academy of Sciences Review Meeting, Columbia, MO (April 2015). http://nas-sites.org/dels/files/2015/05/Day3_01_ITAMURA_NAS-HFIR_04-17-15_FINAL.pdf

18. M. A Pope, H. D. Gougar, J. M. Ryskamp, “Design studies for a multiple application thermal reactor for irradiation experiments (MATRIX),” PHYSOR 2014, Japan ( 2014).

19. Z. Wu, R. E. Williams, S. O’Kelly, "Studies on a new research reactor and cold neutron source at NIST,” International Group on Research Reactors IGORR-16, Bariloche, Argentina (2014).

20. A. S. Icenhour, "Nuclear Science and Engineering Directorate All-Hands Meeting," Oak Ridge National Laboratory (March 30, 2015). 
APPENDIX A. Agenda of the ORNL Workshop on May 12, 2015 

APPENDIX A: AGENDA OF THE ORNL WORKSHOP ON MAY 12, 2015

NEEDS AND REQUIREMENTS FOR FUTURE RESEARCH REACTORS

\author{
ORNL Workshop \\ All ORNL staff are welcome to attend \\ Building 5100, Room 128 \\ May 12, 2015
}

\title{
Morning agenda
}

\begin{tabular}{|c|c|c|c|}
\hline Time & Event & Presenter & Affiliation \\
\hline 8:30am & Logistics/agenda & Germina Ilas & Reactor and Nuclear Systems Division \\
\hline 8:40am & Welcome message & Jess Gehin & $\begin{array}{l}\text { Consortium for Advanced Simulation of } \\
\text { Light Water Reactors (CASL) }\end{array}$ \\
\hline 8:50am & Welcome message & Tim Powers & Research Reactor Division \\
\hline 9:00am & Current HFIR capabilities and metrics & Chris Bryan & Research Reactor Division \\
\hline 9:20am & $\begin{array}{l}\text { Requirements for neutron radiography } \\
\text { and computed tomography research at } \\
\text { future research reactors }\end{array}$ & Hassina Bilheux & Neutron Sciences Directorate \\
\hline 9:40am & $\begin{array}{l}\text { Application of research reactors for } \\
\text { nuclear materials science }\end{array}$ & Roger Stoller & Material Science and Technology Division \\
\hline 10:00am & \multicolumn{3}{|l|}{ Coffee break } \\
\hline 10:15am & $\begin{array}{l}\text { Future research needs for } \\
\text { environmental and ecosystem science }\end{array}$ & Melanie Mayes & Environmental Sciences Division \\
\hline 10:35am & $\begin{array}{l}\text { Neutron technologies for bioenergy } \\
\text { research: the view from simulation }\end{array}$ & Loukas Petridis & Biosciences Division \\
\hline 10:55am & Neutron imaging of fuel injectors & Derek Splitter & $\begin{array}{l}\text { Energy and Transportation Science } \\
\text { Division }\end{array}$ \\
\hline 11:15am & $\begin{array}{l}\text { Neutron scattering instrumentation at a } \\
\text { reactor-based continuous neutron } \\
\text { source }\end{array}$ & Ken Herwig & Neutron Sciences Directorate \\
\hline 11:35am & $\begin{array}{l}\text { Trace element forensics - facilities and } \\
\text { capabilities in the post-HFIR reality }\end{array}$ & David Glasgow & Chemical Sciences Division \\
\hline $11: 55 \mathrm{pm}$ & \multicolumn{3}{|l|}{ Break } \\
\hline
\end{tabular}




\section{Afternoon agenda}

\begin{tabular}{|l|l|l|l|}
\hline Time & Event & Presenter & Affiliation \\
\hline $1: 00 \mathrm{pm}$ & Logistics/agenda & Chris Bryan & Research Reactor Division \\
\hline $1: 05 \mathrm{pm}$ & Welcome message & Paul Langan & Neutron Sciences Directorate \\
\hline $1: 15 \mathrm{pm}$ & Welcome message & John Wagner & Reactor and Nuclear Systems Division \\
\hline $1: 25 \mathrm{pm}$ & $\begin{array}{l}\text { Learning from the Advanced } \\
\text { Neutron Source project }\end{array}$ & Jess Gehin & $\begin{array}{l}\text { Consortium for Advanced Simulation of } \\
\text { Light Water Reactors (CASL) }\end{array}$ \\
\hline $1: 45 \mathrm{pm}$ & $\begin{array}{l}\text { Pu-238 and Cf-252 production in the } \\
\text { HFIR }\end{array}$ & Robert Wham & $\begin{array}{l}\text { Nuclear Security and Isotope Technology } \\
\text { Division }\end{array}$ \\
\hline 2:05 pm & $\begin{array}{l}\text { Thoughts on material irradiation in a } \\
\text { reactor environment }\end{array}$ & Phil Ferguson & $\begin{array}{l}\text { Fusion and Materials for Nuclear Systems } \\
\text { Division }\end{array}$ \\
\hline 2:25 pm & $\begin{array}{l}\text { Nuclear security R\&D needs for } \\
\text { future research reactors }\end{array}$ & David Williams & $\begin{array}{l}\text { Nuclear Security and Isotope Technology } \\
\text { Division }\end{array}$ \\
\hline 2:45 pm & Coffee break & \multicolumn{2}{|l|}{} \\
\hline $3: 00 \mathrm{pm}$ & $\begin{array}{l}\text { Materials irradiation for a future } \\
\text { research reactor - what to keep and } \\
\text { what to throw away }\end{array}$ & Joel McDuffee & Reactor and Nuclear Systems Division \\
\hline 3:20 pm & $\begin{array}{l}\text { Actinide isotopes for super-heavy } \\
\text { element research }\end{array}$ & Jim Roberto & Science \& Technology Partnerships \\
\hline 3:40 pm & $\begin{array}{l}\text { Production of medical and industrial } \\
\text { isotopes at HFIR }\end{array}$ & Saed Mirzadeh & $\begin{array}{l}\text { Nuclear Security and Isotope Technology } \\
\text { Division }\end{array}$ \\
\hline 4:00 pm & Open discussion & \multicolumn{2}{|l}{} \\
\hline 5:00 pm & Adjourn & \\
\hline
\end{tabular}

